\title{
DAMPAK PENGGUNAAN INPUT PRODUKSI TERHADAP EFISIENSI TEKNIS USAHATANI JAGUNG PROGRAM UPAYA KHUSUS (UPSUS) DI KABUPATEN MUARO JAMBI - INDONESIA
}

\author{
Saidin Nainggolan*, Riri Oktari Ulma \\ Program Studi Agribisnis Fakultas Pertanian Universitas Jambi \\ J1. Lintas Jambi, Muara Bulian, Muaro Jambi, Jambi \\ *Corresponding author: saidinnainggolan@yahoo.com
}

\begin{abstract}
This research aims to analyze the allocation of using production inputs, production, and technical efficiency of maize for UPSUS and non-UPSUS programme of corn farming. This study held in two sample villages, namely: Mekar Sari village and Sogo village which were determined purposively. The sample size was 47 farmers participating in the UPSUS program and 36 non-UPSUS farmers. Simple Random Sampling method is applied in this study. The data collection method used the survey with questionnaire. Cobb Douglas production function method and Chow Test are applied to analyze the data. The measurement of technical efficiency is used the Productivity Function Model. The results showed that the maize UPSUS program was able to significantly increase the allocation of the use of production inputs, productivity and technical efficiency. This means that the UPSUS program can be efficient and successful in achieving its production target of 5 ton/ha and additional production of 0.8 ton/ha.
\end{abstract}

Keywords: UPSUS program, production input, production, technical efficiency

\begin{abstract}
Abstrak: Penelitian ini bertujuan untuk menganalisis alokasi penggunaan input produksi, produksi, dan efisiensi teknis usahatani jagung program UPSUS dan non UPSUS. Penelitian ini mengambil dua desa sampel yaitu Desa Mekar Sari dan Desa Sogo yang ditentukan secara purposive. Jumlah sampel sebanyak 47 petani peserta program UPSUS dan sebanyak 36 petani non UPSUS dengan menggunakan Metode Slovin. Pemilihan sampel menggunakan metode Simple Random Sampling. Metode pengumpulan data menggunakan metode survei dengan bantuan kuesioner. Metode analisis data menggunakan metode fungsi produksi Cobb Douglas dan Uji Chow. Pengukuran efisiensi teknis digunakan model Fungsi Produktivitas. Hasil penelitian menunjukan bahwa program UPSUS jagung mampu meningkatkan alokasi penggunaan input produksi, produktivitas, dan efisiensi teknis secara signifikan. Hal ini berarti program UPSUS dapat berdaya guna dan berhasil guna mencapai sasaran produksi sebanyak 5 ton/ha dan tambahan produksi sebesar 0,8 ton/ha.
\end{abstract}

Kata kunci: program UPSUS, input produksi, produksi, efisiensi teknis

\section{PENDAHULUAN}

Kebutuhan jagung di Indonesia saat ini cukup besar, yaitu mencapai 13,8 juta ton pada tahun 2016. Kebutuhan tersebut dibagi menjadi dua bagian yaitu untuk industri pakan dengan jumlah kebutuhan mencapai 8,6 juta ton dan untuk pangan dengan jumlah kebutuhan mencapai 5,2 juta ton. Hal tersebut meningkat dibandingkan dengan tahun 2015, yaitu 13,1 juta ton. 8,3 juta ton untuk industri pakan dan untuk konsumsi pangan dengan jumlah 4,1 juta ton (Wicaksono, 2017). Untuk memantapkan swasembada komoditas jagung, pemerintah mencanangkan Program Upaya Khusus (UPSUS).

Komoditas Jagung sampai saat ini masih merupakan komoditi strategis kedua setelah 
padi karena di beberapa daerah, jagung masih merupakan bahan makanan pokok kedua setelah beras dan juga menyumbang untuk pakan ternak (Palobo et al., 2019). Peningkatan produksi jagung selain dapat dilakukan melalui Program UPSUS, juga dapat dilakukan melalui usaha perluasan areal dan jenis tanaman yang dibudidayakan, serta kebutuhan alat dan mesin pertanian yang dapat dijadikan sebagai faktor pendukung usahatani, yaitu konsep pengelolaan sumber daya alam berbasis teknologi informasi. Artinya, teknologi, varietas, pupuk, irigasi, alsintan, manajemen, budidaya, kelembagaan, inovasi, kredit, dan sistem agribisnis adalah kunci utama bagi pembangunan pertanian yang berkelanjutan dengan eco-farming estate system.

Adapun maksud dan tujuan diadakannya program upaya khusus ini yaitu bertujuan menyediakan kebutuhan sarana dan prasarana pertanian berupa benih pupuk, alat mesin pertanian, dan sarana produksi lainnya. Kemudian meningkatkan indeks pertanaman (IP) dan produktivitas untuk mendukung pencapaian swasembada berkelanjutan jagung. Sasaran dari program ini yaitu peningkatan produksi jagung. Target capaian produktivitas jagung minimal sebesar 5 ton/ha pada areal tanaman baru dan meningkatnya produktivitas jagung sebesar 0,8 ton/ha pada areal yang ada (existing). Realisasi program pada sebagian daerah belum dapat diterapkan semuanya, namun beberapa diantaranya telah berjalan pada beberapa daerah di Provinsi Jambi dan dalam penerapannya di lapangan berupa bantuan benih, pupuk dan penyediaan alat dan mesin pertanian (Diperta, 2017).

Di Provinsi Jambi salah satu daerah sentra pelaksanaan program UPSUS jagung adalah Kecamatan Kumpeh. Program upaya khusus untuk usahatani jagung di daerah tersebut diarahkan untuk dapat memperbaiki jumlah dan alokasi penggunaan input produksi yang sesuai dengan spesifik lokasi untuk usahatani jagung yang diharapkan meningkatkan produksi. Penggunaan input produksi yang baik akan menghasilkan output yang optimal, dan faktor penentu terhadap besarnya efisiensi teknis. Dalam kaitan ini program upaya khusus jagung diharapkan berpengaruh terhadap ketersediaan input produksi, peningkatan kemampuan petani dalam menggunakan input produksi dan peningkatan produktivitas.

\section{METODE PENELITIAN}

Penelitian ini dilaksanakan di Kabupaten Muaro Jambi dengan lokasi penelitian Desa Mekar Sari dan Desa Sogo. Pemilihan dilakukan secara sengaja (purposive) dengan pertimbangan bahwa Desa Mekar Sari merupakan daerah yang mendapatkan program UPSUS dan Desa Sogo tidak mendapatkan program UPSUS. Jumlah sampel sebanyak 47 petani untuk peserta program UPSUS dan 36 petani untuk program non-UPSUS dilakukan dengan menggunakan metode Slovin. Penarikan sampel dilakukan dengan simple random sampling method.

$\log Y_{u}=\log b_{0}+b_{1} \log X_{1}+b_{2} \log X_{2}+b_{3} \log X_{3}+b_{4} \log X_{4}+b_{5} \log X_{5}+b_{6} \log X_{6}+b_{7} \log X_{7}+d X 8+e^{u}$

$\log \mathrm{Y}_{\mathrm{Nu}}=\log \mathrm{b}_{0}+\mathrm{b}_{1} \log \mathrm{X}_{1}+\mathrm{b}_{2} \log \mathrm{X}_{2}+\mathrm{b}_{3} \log \mathrm{X}_{3}+\mathrm{b}_{4} \log \mathrm{X}_{4}+\mathrm{b}_{5} \log \mathrm{X}_{5}+\mathrm{b}_{6} \log \mathrm{X}_{6}+\mathrm{b}_{7} \log \mathrm{X}_{7}+\mathrm{d}_{0} \mathrm{X} 8+\mathrm{e}^{\mathrm{u}}$

\section{Dimana:}

$\mathrm{Y}_{\mathrm{u}} \quad=$ Produksi Jagung petani peserta program UPSUS $(\mathrm{kg})$

$\mathrm{Y}_{\mathrm{Nu}} \quad=$ Produksi Jagung petani bukan peserta program UPSUS $(\mathrm{kg})$

$\mathrm{X}_{1} \quad=$ Luas lahan (ha)

$\mathrm{X}_{2}=$ Tenaga kerja $(\mathrm{HOK})$

$\mathrm{X}_{3}=$ Benih $(\mathrm{kg})$

$\mathrm{X}_{4} \quad=$ Pupuk Urea $(\mathrm{kg})$

$\mathrm{X}_{5} \quad=$ Pupuk Phonska $(\mathrm{kg})$

$\mathrm{X}_{6}=$ Decis $(\mathrm{ml})$

$\mathrm{X}_{7}=$ Gramaxone $(\mathrm{L})$

$\mathrm{D} \quad=1$ (Variabel Dummy untuk petani peserta program UPSUS)

$\mathrm{D} \quad=0$ (Variabel Dummy untuk petani bukan peserta program UPSUS)

$\mathrm{b}_{1}-\mathrm{b}_{7}=$ Pameter penduga

a $\quad=$ Parameter yang berfungsi sebagai intersep

$\mathrm{e} \quad=$ error term. 
Metode analisis data yang digunakan adalah analisis deskriptif dan analisis kuantitatif. Untuk pendekatan estimasi fungsi produksi kedua golongan petani menggunakan model fungsi produksi Cobb-Douglas seperti dalam persamaan (1) dan (2).

Fungsi produksi aktual dapat diestimasi dengan metode Ordinary Least Square (OLS), sedangkan untuk fungsi produksi potensial (fungsi produksi frontier) diestimasi dengan metode Maximum Likelihood Estimation (MLE). Sementara itu, untuk melihat apakah masing-masing koefisien signifikan atau tidak, maka dilakukan dengan menggunakan alat uji hipotesis t statistik dan F statistik (uji Chow).

Uji F statistik (uji Chow) atau signifikansi fixed effect dimaksudkan untuk perbandingan model mana yang paling berpengaruh terhadap variabel dependen secara bersama-sama. Nilai F hitung diperoleh dengan rumus (3).

$\mathrm{F}=\frac{\frac{(\mathrm{RSSR}-\mathrm{RSSUR})}{\mathrm{K}}}{\frac{(\mathrm{RSSUR})}{(\mathrm{n} 1+\mathrm{nI}-\mathrm{ak})}} \sim \mathrm{F}[\mathrm{k},(\mathrm{n} 1+\mathrm{n} 2-2 \mathrm{k})]$

Dimana:

RSS = Koefisien determinan berganda

$\mathrm{K}$ = Banyaknya variabel bebas

$\mathrm{N} \quad=$ Banyaknya sampel
Nilai $\mathrm{F}$ Chow yang didapat selanjutnya dibandingkan dengan nilai $\mathrm{F}$ tabel pada derajat bebas (df) tertentu dengan tingkat keyakinan tertentu dengan keputusan sebagai berikut:

$$
\begin{aligned}
& \mathrm{F}_{\text {chow }} \leq \mathrm{F}_{\text {tabel }}(\mathrm{k} ; \mathrm{db}=\mathrm{n}-2) \rightarrow \mathrm{H}_{0} \text { diterima } \\
& \mathrm{F}_{\text {chow }}>\mathrm{F}_{\text {tabel }}(\mathrm{k} ; \mathrm{db}=\mathrm{n}-2) \rightarrow \mathrm{H}_{0} \text { ditolak } \\
& \mathrm{H}_{0}= \begin{array}{l}
\text { Tidak terdapat perbedaan fungsi } \\
\text { produksi (intersep dan slope) antara }
\end{array} \\
& \text { UPSUS dan non UPSUS secara nyata. } \\
& \mathrm{H}_{1}= \begin{array}{l}
\text { Terdapat perbedaan fungsi produksi } \\
\text { (intersep dan slope) antara UPSUS dan }
\end{array} \\
& \text { non UPSUS secara nyata. }
\end{aligned}
$$

\section{HASIL DAN PEMBAHASAN}

\section{Deskripsi Petani Responden}

Deskripsi karakteristik petani sampel bertujuan untuk menggambarikan kondisi sosial ekonomi petani. Kondisi ini menjadi beberapa faktor yang mempengaruhi keputusan petani dalam mengelola usahataninya. Adapun gambaran karakteristik petani sampel disajikan pada Tabel 1.

Tabel 1 menunjukkan bahwa umur

\begin{tabular}{|c|c|c|c|c|}
\hline \multirow{2}{*}{ No. } & \multirow{2}{*}{ Penggunaan Input } & UPSUS & Non-UPSUS & \multirow{2}{*}{$\begin{array}{c}\text { Selisih } \\
(\Delta)\end{array}$} \\
\hline & & Rata-rata & Rata-rata & \\
\hline 1. & Luas lahan (ha) & 1,60 & 1,10 & $0,50^{*}$ \\
\hline 2. & Tenaga Kerja (HOK/ha) & 80,26 & 66,42 & $13,84 *$ \\
\hline 3. & Benih $(\mathrm{kg} / \mathrm{ha})$ & 16,5 & 13 & $3,5^{\mathrm{ns}}$ \\
\hline 4. & Pupuk Urea (kg/ha) & 141,84 & 97,92 & $44,35 * *$ \\
\hline 5. & Pupuk Phonska (kg/ha) & 95,58 & 49,45 & $46,13 * *$ \\
\hline 6. & Decis (ml/ha) & 961,85 & 297,43 & $664,42 * *$ \\
\hline 7. & Gramaxone (1/ha) & 3,35 & 2,14 & $1,21^{*}$ \\
\hline
\end{tabular}
petani berada pada usia produktif, pengalaman usahatani tergolong baik, pendidikan formal tergolong rendah, luaas lahan cukup luas, dan petani aktif dalam kelompok taninya.

Tabel 1. Karakteristik Petani Daerah Penelitian

\begin{tabular}{lccc}
\hline \multirow{2}{*}{ Karakteristik } & \multirow{2}{*}{ Sebaran } & \multicolumn{2}{c}{ Rata-rata } \\
\cline { 3 - 4 } & & UPSUS & Non UPSUS \\
\hline Umur (Tahun) & $29-60$ & 44 & 46 \\
Pengalaman Usahatani (Th) & $5-28$ & 11,5 & 13,5 \\
Pendidikan Formal (Th) & $5-12$ & 6 & 8,5 \\
Jumlah Anggota Keluarga (org) & $5-8$ & $5-6$ & $7-8$ \\
Luas Lahan (ha) & $0,85-2,5$ & 0,88 & 1,25 \\
Keaktifan dalam Kelompok Tani & - & Cukup Aktif & Tidak Aktif \\
\hline
\end{tabular}

Tabel 2. Rata-Rata Penggunaan Input di Daerah Penelitian

Ket. $\left(^{*}\right)$ berbeda pada taraf $\alpha(0,05),(* *)$ berbeda pada taraf $\alpha(0,01)$, (ns) tidak signifikan 
Gambaran Penggunaan Input Produksi Petani UPSUS dan Non-UPSUS

Alokasi penggunaan input produksi yang lebih mendekati dosis anjuran pada petani peserta program UPSUS adalah gambaran pengaruh pelaksanaan program UPSUS. Penggunaan input produksi usahatani Jagung kedua golongan petani petani program UPSUS dan non-UPSUS dapat dilihat pada Tabel 2.

Tabel 2 menunjukkan bahwa penggunaan input produksi pupuk urea, phonska, dan decis adalah berbeda sangat signifikan. Penggunaan luas lahan tenaga kerja dan gramaxone adalah berbeda secara signifikan. Sedangkan penggunaan benih tidak berbeda secara signifikan. Hal ini berarti bahwa program UPSUS berpengaruh terhadap peningkatan penggunaan input produksi secara signifikan Penggunaan benih oleh petani program UPSUS yaitu $16,5 \mathrm{~kg} / \mathrm{ha}$. Penggunaan benih ini telah sesuai rekomendasi dari Kepala Balai Penyuluhan Pertanian sebanyak 15-17 $\mathrm{kg} / \mathrm{ha}$. Petani program UPSUS menggunakan pupuk urea sebanyak $141,84 \mathrm{~kg} / \mathrm{ha}$ sedangkan petani non-UPSUS sebanyak $97,92 \mathrm{~kg} / \mathrm{ha}$. Dosis anjuran pupuk urea 250 - $350 \mathrm{~kg} / \mathrm{ha}$.
Penggunaan pupuk phonska untuk petani UPSUS dan non-UPSUS masih tergolong rendah. Dosis anjuran pupuk phonska 150 $200 \mathrm{~kg} / \mathrm{ha}$. Penggunaan pupuk yang tidak sesuai dosis anjuran dapat menyebabkan produksi yang tidak maksimal. Penggunaan obat-obatan petani UPSUS jumlahnya tergantung serangan gulma, hama dan penyakit.

\section{Dampak Program UPSUS Terhadap Peningkatan Produksi Usahatani Jagung}

Dampak program UPSUS dapat dilihat dari kinerja petani, yaitu produktivitas. Terdapat perbedaan produktivitas yang sangat signifikan antara kedua golongan petani. Produksi usahatani program UPSUS $4.393 \mathrm{~kg} / \mathrm{ha}$. Sedangkan produksi non-UPSUS $2.525 \mathrm{~kg} / \mathrm{ha}$. Peningkatan produktivitas sebesar 1,87 ton/ha dan melebihi target capaian tambahan produktivitas sebesar 0,8 ton/ha. Hal ini berarti program UPSUS jagung berpengaruh terhadap peningkatan produktivitas secara sangat signifikan. Hasil uji asumsi klasik menunjukkan bahwa model fungsi produksi Cobb-Douglas yang digunakan memenuhi syarat untuk digunakan sebagai penduga.

Tabel 3. Hasil Estimasi Fungsi Produksi Usahatani Jagung Kedua Golongan Petani Daerah Penelitian

\begin{tabular}{|c|c|c|c|c|}
\hline \multirow[b]{2}{*}{ Variable } & \multicolumn{4}{|c|}{ Coefficient } \\
\hline & Upsus & Non- upsus & $\begin{array}{l}\text { Upsus dan Non- } \\
\text { upsus Tanpa } \\
\text { Dummy }\end{array}$ & $\begin{array}{c}\text { Upsus dan } \\
\text { Non-upsus } \\
\text { dengan } \\
\text { Dummy }\end{array}$ \\
\hline Log_X ${ }_{1}($ Luas Lahan) & $\begin{array}{l}0.53241 \\
(0.0000)\end{array}$ & $\begin{array}{l}0.34562 \\
(0.0000)\end{array}$ & $\begin{array}{l}0.23562 \\
(0.0149)\end{array}$ & $\begin{array}{l}0.54325 \\
(0.0000)\end{array}$ \\
\hline Log_X ${ }_{2}($ T.Kerja $)$ & $\begin{array}{l}0.17865 \\
(0.0285)\end{array}$ & $\begin{array}{l}0.19921 \\
(0.1571)\end{array}$ & $\begin{array}{l}0.11453 \\
(0.1006)\end{array}$ & $\begin{array}{l}0.15467 \\
(0.0003)\end{array}$ \\
\hline $\log _{-} X_{3}($ Benih $)$ & $\begin{array}{l}0.42246 \\
(0.0032)\end{array}$ & $\begin{array}{l}0.31142 \\
(0.0330)\end{array}$ & $\begin{array}{l}0.32346 \\
(0.0000)\end{array}$ & $\begin{array}{l}0.36474 \\
(0.0011)\end{array}$ \\
\hline Log_X $\mathrm{X}_{4}($ Urea $)$ & $\begin{array}{l}0.43567 \\
(0.0021)\end{array}$ & $\begin{array}{l}0.18765 \\
(0.0173)\end{array}$ & $\begin{array}{l}0.25462 \\
(0.0044)\end{array}$ & $\begin{array}{l}0.13454 \\
(0.0030)\end{array}$ \\
\hline Log_X $X_{5}($ Phonska $)$ & $\begin{array}{l}0.28756 \\
(0.0006)\end{array}$ & $\begin{array}{l}0.16865 \\
(0.0419)\end{array}$ & $\begin{array}{l}0.011243 \\
(0.0216)\end{array}$ & $\begin{array}{l}0.15467 \\
(0.0134)\end{array}$ \\
\hline $\log X_{6}($ Decis $)$ & $\begin{array}{l}0.12275 \\
(0.4361)\end{array}$ & $\begin{array}{l}0.01428 \\
(0.0367)\end{array}$ & $\begin{array}{l}0.09872 \\
(0.0232)\end{array}$ & $\begin{array}{l}0.13274 \\
(0.0004)\end{array}$ \\
\hline Log_X ${ }_{7}($ Gramaxone $)$ & $\begin{array}{c}0.099978 \\
(0.0628)\end{array}$ & $\begin{array}{l}0.01029 \\
(0.1034)\end{array}$ & $\begin{array}{l}0.02114 \\
(0.1087)\end{array}$ & $\begin{array}{l}0.09874 \\
(0.0511)\end{array}$ \\
\hline D_X X $_{8}$ Dummy $)$ & 0 & 0 & 0 & $\begin{array}{l}0.06754 \\
(0.0000)\end{array}$ \\
\hline $\mathrm{C}$ & $\begin{array}{l}4.43562 \\
(0.0000) \\
\end{array}$ & $\begin{array}{r}3.95667 \\
(0.0000) \\
\end{array}$ & $\begin{array}{r}4.12256 \\
(0.0000) \\
\end{array}$ & $\begin{array}{l}4.61265 \\
(0.0000) \\
\end{array}$ \\
\hline Adj. $R^{2}$ & 0,92356 & 0,88723 & 0,85704 & 0,96706 \\
\hline
\end{tabular}

Keterangan : ()$\rightarrow$ menunjukan Sig 
Hasil uji normalitas menunjukkan nilai jargueBera sebesar 0,9066 dengan p.value sebesar $0,6355>0,05$, artinya data berdistribusi secara normal, nilai p.value ditunjukkan dengan nilai Pro Chi-Square (8) pada Obs* $\mathrm{R}^{2}$ yaitu sebesar $1,812>0,05$ maka model tidak masalah dengan Heteroskedasitas. Nilai Durbin-Watson 1,8 dan nilai Prob Chi-Square 0,2552 > 0,05 berarti model bebas dari autokorelitas. Uji Multikolinieritas dilihat dari nilai $\mathrm{V} / \mathrm{F}_{1}-\mathrm{x} 8<$ 10 maka dapat dinyatakan tidak terdapat multikolinieritas di dalam model. Adapun hasil estimasi fungsi produksi kedua golongan usahatani jagung dapat dilihat pada Tabel 3 .

Tabel 3 menunjukkan dari keempat model estimasi fungsi produksi usahatani jagung didapatkan hasil Adj. $R^{2}$ tertinggi sebesar 0,96706 setelah diuji model ini terbebas dari uji asumsi klasik. Maka dari itu, pembahasan lebih lanjut akan berfokus pada estimasi fungsi produksi peserta program UPSUS dan nonUPSUS dengan (dummy) saja.

Nilai Adj. $R^{2}$ tertinggi sebesar $=0,96706$ hal ini berarti $96,71 \%$ variasi produksi jagung dapat dijelaskan secara simultan oleh variabel input produksi (luas lahan, tenaga kerja, benih, pupuk urea, pupuk phonska, decis dan gramaxone) sedangkan sisanya 3,29 \% dipengaruhi oleh faktor lainnya diluar model. Faktor input produksi yang berpengaruh nyata terhadap produksi (output) adalah luas lahan, benih, pupuk phonka, decis, dan dummy $\{$ DX8 $\}$.Variabel dummy $\{$ DX8 $\}$ menunjukkan prob. $0,000<$ alfa $\{0,01\}$ artinya berbeda sangat nyata. Dengan kata lain program UPSUS mampu meningkatkan produksi jagung secara sangat nyata. Pengaruh penggunaan input produksi secara simultan terhadap produksi jagung dapat diketahui dengan menggunakan uji $\mathrm{F}$, dari hasil analisis diperoleh $\mathrm{F}_{\text {statistic }}$ sebesar 271.0523 dengan prob. $0,0000<\alpha$ $(0,01)$, artinya berbeda sangat nyata. Hal ini berarti variable input produksi yang terdapat dalam model secara simultan berpengaruh sangat nyata terhadap produksi jagung.

\section{Uji Perbandingan Model Fungsi Usahatani Jagung}

Hasil estimasi perbandingan fungsi produksi usahatani jagung program UPSUS dan non UPSUS dengan menggunakan uji chow dapat dilihat Tabel 4.

Tabel 4 menunjukan bahwa terdapat perbedaan fungsi produksi usahatani program UPSUS dan non-UPSUS. Hal ini berarti, model fungsi produksi kedua golongan secara terpisah adalah berbeda nyata. Perbedaan produksi terjadi karena adanya perbedaan jumlah input produksi yang digunakan. Perbedaan produksi ini secara nyata disebabkan karena adanya pengaruh program UPSUS terhadap peningkatan produksi jagung. Hal ini sejalan dengan penelitian Silitonga et al. (2016) yang menyatakan bahwa terdapat perbedaan yang sangat nyata antara model III dan model IV pada petani jagung PTT dan petani bukan PTT. Perbedaan model tersebut disebabkan oleh adanya dummy variabel pada model IV yang berarti terdapat perbedaan intersep antara kedua model.

\section{Hasil Estimasi Fungsi Produktivitas Usahatani Jagung}

Nilai efisiensi teknis menggambarkan rasio produksi aktual terhadap produksi frontier. Adapun hasil estimasi fungsi produktivitas kedua golongan usahatani dapat dilihat Tabel 5. Tabel 5 menunjukkan bahwa nilai Adj. $\mathrm{R}^{2}$ $=0,6346$, hal ini berarti $63,46 \%$ variasi produktivitas mampu dijelaskan secara simultan oleh variabel input produksi (tenaga kerja, benih, pupuk urea, pupuk phonska, decis dan gramaxone)

Tabel 4. Hasil Perhitungan Uji Perbandingan Model dengan Uji Chow

\begin{tabular}{|c|c|c|c|c|c|c|}
\hline \multirow{2}{*}{ Model Fungsi } & \multirow{2}{*}{ SSR } & \multirow{2}{*}{ SE } & \multirow{2}{*}{$\mathrm{K}-1$} & \multirow{2}{*}{ Fhit } & \multicolumn{2}{|c|}{ Ftabel } \\
\hline & & & & & $\propto=0,05$ & $\propto=0,01$ \\
\hline Upsus & 0,404959 & 0,101900 & 7 & & & \\
\hline Non-Upsus & 0,565105 & 0,104554 & 7 & 3,26 & 2,07 & 2,77 \\
\hline $\begin{array}{l}\text { Upsus +Non-Upsus } \\
\text { (Tanpa dummy) }\end{array}$ & 2.154 .931 & 0,169506 & 7 & & & \\
\hline $\begin{array}{l}\text { Upsus +Non-Upsus } \\
\text { ( Dengan Dummy) }\end{array}$ & 1,437804 & 0,139391 & 8 & 12,64 & 2,07 & 2,77 \\
\hline
\end{tabular}


Saidin N., Riri O. U. : Dampak Penggunaan Input Produksi Terhadap ...

Tabel 5. Hasil Estimasi Fungsi Produktivitsas Usahatani Jagung Program UPSUS dan Non UPSUS Daerah Penelitian, Tahun 2018

\begin{tabular}{|c|c|c|c|c|}
\hline \multirow{2}{*}{ Variabel } & \multicolumn{2}{|c|}{ Program Upsus } & \multicolumn{2}{|c|}{ Program Non-Upsus } \\
\hline & Coeficient & Sig. & Coeficient & Sig. \\
\hline Log_X $X_{1}($ Tenaga Kerja) & 0,346562 & $(0,0045)$ & 0,114334 & $(0,1042)$ \\
\hline Log_X $X_{2}($ Benih $)$ & 0,298654 & $(0,0038)$ & 0,212256 & $(0,0221)$ \\
\hline Log_X $X_{3}($ Pupuk Urea) & 0,465643 & $(0,0013)$ & 0,187782 & $(0,0000)$ \\
\hline Log_X $X_{4}($ Pupuk Phonska $)$ & 0,287645 & $(0,0012)$ & 0,126672 & $(0,0021)$ \\
\hline $\log _{-} \mathrm{X}_{5}($ Decis $)$ & 0,021562 & $(0,0655)$ & 0,016673 & $(0,0542)$ \\
\hline Log_X 6 (Gramaxone $)$ & 0,086563 & $(0,0824)$ & 0,006675 & $(0,5318)$ \\
\hline $\mathrm{C}$ & 4,333423 & $(0,0000)$ & 3,445632 & $(0,0000)$ \\
\hline
\end{tabular}

Keterangan : () menunjukkan Sig

Tabel 6. Efisiensi Teknis Usahatani Jagung di Daerah Penelitian Tahun 2018

\begin{tabular}{|c|c|c|c|c|}
\hline \multirow[b]{2}{*}{$\begin{array}{c}\text { Interval Efisiensi } \\
\text { Teknis }\end{array}$} & \multicolumn{2}{|c|}{ UPSUS } & \multicolumn{2}{|c|}{ Non-UPSUS } \\
\hline & $\begin{array}{l}\text { Freku } \\
\text { ensi } \\
\text { (Oran } \\
\text { g) }\end{array}$ & $\begin{array}{l}\text { Persenta } \\
\text { se }(\%)\end{array}$ & $\begin{array}{l}\text { Frekuens } \\
\text { i (Orang) }\end{array}$ & $\begin{array}{c}\text { Persenta } \\
\text { se } \\
(\%)\end{array}$ \\
\hline $0,43-0,50$ & 0 & 0 & 15 & 41,67 \\
\hline $0,51-0,58$ & 0 & 0 & 16 & 34,04 \\
\hline $0,59-0,66$ & 7 & 14,90 & 3 & 8,34 \\
\hline $0,67-0,74$ & 37 & 78,72 & 2 & 5,55 \\
\hline $0,75-0,82$ & 2 & 4,26 & 0 & 0 \\
\hline $0,83-0,90$ & 1 & 2,12 & 0 & 0 \\
\hline Jumlah & 47 & 100 & 36 & 100 \\
\hline Et Tertinggi & & 0,90 & & 0,78 \\
\hline Et Terendah & & 0,63 & & 0,43 \\
\hline Rata-Rata ET & & 0,72 & & 0,54 \\
\hline
\end{tabular}

Sedangkan sisanya $36,54 \%$ dipengaruhi oleh faktor- faktor lain diluar model. Nilai elastisitas produktivitas dari variabel tenaga kerja, benih, pupuk urea, pupuk phonska, decis, gramaxone berturut-turut sebesar 0.346562 ; $0.298654 ; \quad 0.465643 ; \quad 0.287645 ; \quad 0.021562$; 0.086563 jika variabel tenaga kerja, benih, pupuk urea, pupuk phonska, decis, gramaxone ditambah sebesar $10 \quad \%$ maka dapat meningkatkan produktivitas masing masing sebesar, $3,46 \% ; 2,29 \% ; 4,65 \% ; 2,87 \% ; 0,2$ $\%$; dan $0,8 \%$ dengan asumsi variabel lainnya ceteris paribus.

Sedangkan untuk usahatani jagung non UPSUS menunjukkan bahwa nilai Adj. $\mathrm{R}^{2}=$ 0,6147, hal ini berarti $61,47 \%$ variasi produktivitas mampu dijelaskan secara simultan oleh variabel input produksi (tenaga kerja, benih, pupuk urea, pupuk phonska, decis, gramaxone) Sedangkan sisanya 38,53\% dipengaruhi oleh faktor faktor lain diluar model. Nilai elastisitas $\mathrm{p}$ roduktivitas dari variabel tenaga kerja, benih, pupuk urea, pupuk phonska, decis, gramaxone berturut-turut sebesar $\quad 0,114334 ; \quad 0,212256 ; \quad 0,187782$; 0,$126672 ; 0,016673 ; 0,006675$ jika variabel tenaga kerja, benih, pupuk urea, pupuk phonska, decis, gramaxone ditambah sebesar $10 \%$ maka dapat meningkatkan produktivitas masing masing sbesar, $1,14 \% ; 2,12 \% ; 1,87 \%$; $1,26 \% ; 0,1 \%$; dan $0,06 \%$ dengan asumsi variable lainnya ceteris paribus.

\section{Dampak Program UPSUS Terhadap Efisiensi Teknis Usahatani Jagung}

Nilai efisiensi teknis dapat diinterpretasikan berwajah ganda. Di satu sisi, tingkat efisiensi yang tinggi mencerminkan prestasi petani dalam keterampilan manajerial cukup tinggi. Di sisi lain, tingkat efisiensi yang tinggi juga merefleksikan bahwa peluang untuk meningkatkan produktivitas yang lebih tinggi semakin kecil karena senjang antara tingkat produktivitas yang telah dicapai dengan tingkat 
produktivitas maksimum yang dapat dicapai dengan sistem pengelolaan terbaik (the best practiced) semakin sempit. Hal ini berarti bahwa untuk meningkatkan produktivitas usahatani secara nyata diperlukan inovasi inovasi baru yang memerlukan kajian teknologi yang berasal dari aktivitas penelitian. Hasil analisis efisiensi teknis usahatani jagung program UPSUS dan non-UPSUS dapat dilihat pada Tabel 6.

Tabel 6 menunjukkan bahwa rata-rata efisiensi teknis pada usahatani jagung petani program peserta UPSUS adalah 0,7256 dengan sebaran 0,63 < ET < 0,90. Hal ini berarti bahwa rata-rata produktivitas yang dicapai petani jagung program UPSUS sekitar 72,56 \% dari produktivitas batas (frontier), yang mengindikasikan besarnya inefisiensi teknis sebesar $27,44 \%$ atau potensi peningkatan produktivitas masih tersedia sebanyak $27,44 \%$. Sedangkan non UPSUS menunjukkan bahwa rata-rata tingkat efisiensi teknis adalah 0,5482 dengan sebaran $0,43<$ ET $<0,74$. Hal ini menunjukkan bahwa rata-rata produktivitas yang dicapai petani jagung program UPSUS sekitar $54,82 \%$ dari produktivitas batas (frontier). Hal ini berarti, besarnya inefisiensi teknis sebesar $0,4518 \quad(45,18 \%)$ atau potensi peningkatan produksi masih tersedia sebanyak $45,18 \%$.

Nilai indeks efisensi teknis hasil analisis dikategorikan efisien jika menghasilkan nlai TE $>$ 0,70 sebagai batas efisiensi (Coelli, 1998). Hal ini menunjukkan bahwa rata-rata usahatani jagung program UPSUS sudah efisien secara teknis $[$ TE $=0,75>0,70]$. Hal ini dikarenakan penggunaan input produksi petani UPSUS ratarata sudah diatur secara efisien. Sedangkan pada petani jagung non UPSUS menunjukkan bahwa rata-rata hasil efisiensi menunjukkan belum efisien secara teknis $[\mathrm{TE}=0,50<0,70]$. Hal ini dikarenakan bahwa usahatani jagung secara umum belum berhasil mengatur penggunaan faktor-faktor input produksi mereka secara efisien sehingga menyebabkan tejadinya inefisiensi. Rendahnya pengetahuan petani dalam mengaplikasikan input yang baik dan benar juga merupakan salah satu faktor yang menyebabkankan petani non UPSUS tidak efisien dalam memproduksi usahatani jagung. Penelitian Mira (2008) di Kabupaten Bangkalan (Madura-Jawa Timur), bahwa usahatani jagung telah mampu mencapai performansi tingkat efisiensi yang mendekati full-efisien secara teknis, karena rata-rata efisiensi teknis yang dicapai sebesar 96,9\% dengan kisaran TE sebesar 0,75-1,00, dan besarnya nilai inefisiensi teknis rata-rata sebesar 3,1\%.

Perbedaan efisiensi teknis oleh petani di lokasi penelitian mengindikasikan tingkat penguasaan dan aplikasi teknologi yang berbeda-beda. Hal tersebut sejalan dengan pendapat Prayoga (2010) dan Murniati et al. (2014) bahwa tingkat penguasaan teknologi yang berbeda-beda disebabkan oleh faktor internal petani seperti pendidikan, umur, pengalaman berusahatani, frekuensi mengikuti penyuluhan dan faktor ekternal seperti musim tanam, strategi adaptasi dan persepsi terhadap dampak perubahan iklim. Banyak faktor yang dapat mempengaruhi eisiensi teknis, salah satu di antaranya adalah pendampingan dan pengawalan.

\section{KESIMPULAN DAN SARAN}

Berdasarkan analisis yang dilakukan dapat ditarik kesimpulan bahwa terdapat perbedaan pengunaan input produksi secara signifikan kecuali penggunaan benih. Perbedaan penggunaan input produksi terjadi karena adanya program UPSUS jagung. Terdapat perbedaan produksi dan produktivitas kedua golongan petani secara signifikan. Perbedaan ini terjadi karena perbedaan penggunaan input produksi. Penggunaan input produksi secara simultan berpengaruh sangat nyata terhadap produksi usahatani jagung program UPSUS dan non UPSUS. Penggunaan input produksi secara parsial luas lahan, benih, pupuk urea, pupuk phonska berpengaruh signifikan terhadap produksi. Untuk usahatani non-UPSUS tingkat produksi dipengaruhi secara sangat nyata oleh luas lahan, urea, pupuk phonska, dan decis. Efisiensi teknis usahatani jagung program UPSUS lebih tinggi dibandingkan usahatani non-UPSUS, yang berarti program UPSUS mampu meningkatkan efisiensi teknis usahatani jagung. Dengan kata lain, program UPSUS mampu meningkatkan produksi melalui peningkatan input produksi. Karena itu, perlu perluasan program UPSUS kepada petani jagung lainnya, menambah bantuan sarana produksi dan bantuan modal kerja. 
Saidin N., Riri O. U. : Dampak Penggunaan Input Produksi Terhadap ...

\section{DAFTAR PUSTAKA}

BPS Provinsi Jambi. 2016 . Jambi dalam Angka. Jambi: Badan Pusat Statistik Provinsi Jambi.

Coelli, T.J., Rao, D.S.P., Battese, G.E. 1998. An Introduction to Efficiency and Productivity Analysis. Boston: KluwerNijhoff.

Diperta. 2017. Laporan Dinas Pertanian Tanaman Pangan dan Hortikultura. Muaro Jambi: Diperta Kabupaten Muaro Jambi.

Kementerian Pertanian. 2015. Peraturan Menteri Pertanian nomor 3 tahun 2015 tentang Pedoman Upaya Khusus (UPSUS) Peningkatan Produksi Padi, Jagung, dan Kedelai. Jakarta: Kementerian Pertanian.

Mira, A.R.D. 2008. Analisis Efisiensi Teknis Penggunaan Faktor Produksi pada Usahatani Jagung (Zea mays) (Studi Kasus Desa Kramat, Kecamatan Bangkalan, Kabupaten Bangkalan, Madura). Skripsi. Fakultas Pertanian. Universitas Brawijaya.
Murniati, K., Mulyo, J.H., Irham, dan Hartono, S. 2014. Efisiensi Teknis Usahatani Padi Organik Lahan Sawah Tadah Hujan Di Kabupaten Tanggamus Provinsi Lampung. Jurnal Penelitian Pertanian Terapan, 14 (1), 31- 38.

Palobo, F., Masbaitubun, H., dan Tirajoh, S. 2019. Analisis Kelayakan Usahatani Jagung Hibrida pada Lahan Kering Di Merauke, Papua. SEPA, 16 (1) : 1-10.

Prayoga, A. 2010. Produktivitas dan Efisiensi Teknis Usahatani Padi Organik Lahan Sawah. Jurnal Agro Ekonomi, 28 (1), $1-19$.

Silitonga, Y., Haryanto, Sinaga, B.M., dan Rusastra, I.W. 2016. Analisis Efisiensi Usahatani Jagung pada Lahan Kering melalui Penerapan Pengelolaan Tanaman Terpadu (PTT) di Provinsi Jawa Barat. Jurnal Informatika Pertanian, 25 (2), $199-214$.

Wicaksono. (2017/12/28). Kebutuhan Jagung Nasional. Retrieved from http://bisnis.liputan6.com/read/2386889/ kebutuhan-jagung-nasional-capai-138juta-tondi-2016. 